\title{
Experimental study on full-penetration friction stir welding of 2219 aluminum alloy
}

\author{
Sun Qian', Zhou Hong' ${ }^{2}, W u$ Zaihou $^{2}$ \\ ${ }^{1}$ School of Marine Engineering, Jimei University, Xiamen, Fujian, \\ 361021, China \\ ${ }^{2}$ School of Ocean and Civil Engineering, Jiangsu University of Science and \\ Technology, Zhenjiang, Jiangsu,212003, China
}

Received October 20, 2018

\begin{abstract}
This paper takes 2219 aluminum alloy as the object of study, makes an experiment of full-penetration friction stir welding (FSW). The effectiveness of three kinds of full penetration procedure are verified by using technology of X-ray flaw test and root color test, and the differences of mechanical property of weld bead of three FSW have been analyzed based on mechanical property and metallographic tests. Through the experiment, the FSW of back supporting can be proved to be the most suitable welding procedure for production.
\end{abstract}

Keywords: Aluminum alloy, full penetration, friction stir welding.

Анализируется сварка методом трения с перемешиванием (FSW) алюминиевого сплава 2219. Эффективность трех видов перемешивания проверяется испытаниями механических свойств шва металлографическим методом, методом рентгеновской дефектоскопии и цветовым методом. Показано, что FSW задней поддержки является наиболее подходящей процедурой сварки для производства.

Експериментальне дослідження зварювання тертям 3 перемішуванням алюмінісвого сплаву 2219. Sun Qian, Zhou Hong, Wu Zaihou.

Вивчається зварювання методом тертя з перемішуванням (FSW) алюмінієвого сплаву 2219. Ефективність трьох видів перемішування перевіряється випробуваннями механічних властивостей шва металографічним методом, методом рентгенівської дефектоскопії і колірним методом. Показано, що FSW задньої підтримки є найбільш придатною процедурою зварювання для виробництва.

\section{Introduction}

Aluminum alloy has been widely used in the shipbuilding industry, but it is difficult to avoid the defects of pores in welds and welding slag, so it is difficult to meet the requirements of ship design and manufacture. Friction stir welding (FSW), a solid phase connection technology is mainly used in the manufacture of aluminum flat structural parts, especially large aluminum alloy wall structures in shipbuilding [1-4]. The friction stir welding of 2219 aluminum alloy will carried out in this paper, and the test results will be analyzed in detail.

\section{Experimental}

2.1. Operation test materials and testing equipment

The welding sample used in the full penetration friction stir welding test is made of aluminum alloy 2219-T62. 2219 aluminum alloy has good weldability, resistance to stress corrosion, excellent mechanical properties and fracture toughness in the 
Table 1. Main chemical composition of 2219 aluminum alloy (1-1)

\begin{tabular}{|c|c|c|c|c|c||}
\hline Alloy & $\mathrm{Cu}, \%$ & $\mathrm{Mn}, \%$ & $\mathrm{Fe}, \%$ & $\mathrm{Si}, \%$ & $\mathrm{Mg}, \%$ \\
\hline $\mathrm{Al}-\mathrm{Cu}$ & $5.8 \sim 6.8$ & $0.2 \sim 0.4$ & 0.3 & $0 . \%$ & 0.02 \\
\hline
\end{tabular}

\begin{tabular}{|c|c|c|c|c||}
\hline \hline Alloy & $\mathrm{Zn}, \%$ & $\mathrm{Zr}, \%$ & $\mathrm{Ti}, \%$ & $\mathrm{Al}, \%$ \\
\hline $\mathrm{Al}-\mathrm{Cu}$ & 0.1 & $0.1 \sim 0.25$ & $0.02 \sim 0.1$ & Residual quantity \\
\hline
\end{tabular}

temperature range of -250 to $250^{\circ} \mathrm{C}$ [5]. Table 1 is a 2219 aluminum alloy composition table.

In the full penetration and friction stir welding test, the mixing tool is chosen as the concave shaft shoulder, and the stirring probe is a cone-shaped threaded structure [6]. The diameter of the shaft shoulder is 22 $\mathrm{mm}$, and the diameter of the stirred probe's root is $6.4 \mathrm{~mm}$. The stirring probe length of the number two test sample is $5.8 \mathrm{~mm}$, the thickness of backing plate is $0.5 \mathrm{~mm}$, and length of the other stirring probes is 5.4 mm. The CFST two-dimensional friction stir welding equipment is selected for the welding experiment. Unified process parameters are used in the test, the rotating speed of the stirring tool is $400 \mathrm{r} / \mathrm{min}$, welding speed is $100 \mathrm{~mm} / \mathrm{min}$, feed quantity is controlled in $0.2 \mathrm{~mm}$ to $0.3 \mathrm{~mm}$.

\subsection{Test scheme for full penetration fric-} tion stir welding

Four pairs of samples are chosen for the full penetration test. The common friction stir welding (FSW) procedure, the back plate welding procedure, the shoe plate slotting welding procedure and the root slotting welding procedure are used respectively. As shown in Fig. (1), they are marked as 1\#, $2 \#, 3 \#$ and $4 \#$, respectively.

The length of the 2219-T62 specimen used for welding is $400 \mathrm{~mm}$, the width is $100 \mathrm{~mm}$, and the thickness is variable thickness. The starting thickness is $5.2 \mathrm{~mm}$, and the thickness of the workpiece increases continuously along the welding direction to $6 \mathrm{~mm}$ at the end.

The method of verification of full penetration test uses ray flaw detection and root coloring to detect the weld bead of unequal thickness specimens of four kinds of procedure, and verifies the effectiveness of the full penetration process [7].

Intercepting the full penetration weld specimen in the above procedure for the performance test of the weld root, with the

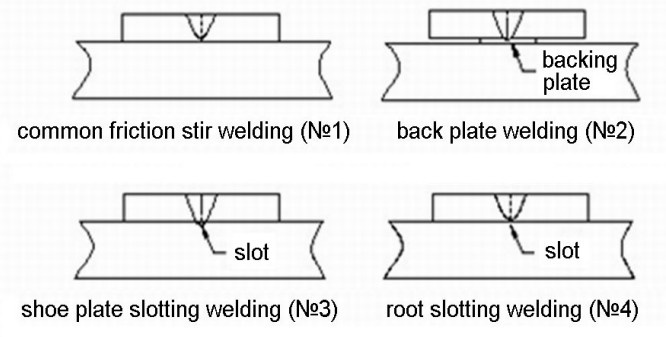

Fig. 1. A sketch map of four kinds of friction stir welding.

same number, it is divided into the following two steps:

The tensile test and the bending test of the bead root, the mechanical tensile and bending test equipment are SANS universal drawframe with the model of XYB305C, in which the average value of the four pieces of the tensile and bending properties is taken;

Metallographic analysis of weld root microstructure is made by ZEISS metallographic microscope and model of ProgRes-C5.

\section{The results and discussion}

In order to understand the welding penetration of four kinds of friction stir welding procedure, radiographic inspection and root coloring test for four welding samples are carried out [8]. Figs. $2 \mathrm{a}-\mathrm{d}$ is №1-4 radiographic inspection photos. We can see that there is no incomplete penetration defect in radiographic inspection. One white thick line in the photo of №3 specimen is the position of the groove.

Fig. 3. shows the results of the root coloring test, of which No. 2, 3, and 4 specimens are found to have no weld defects, and No.1 test sample is found lack of penetration, and is marked in (a). Compared with radiographic inspection results, it can be see that for root defects detection, root coloring detection has relatively higher accuracy.

The results of radiographic and root coloring tests show that the three types of fully penetrated friction stir welding proce- 
Table 2. Test sheet for tensile properties of the weld joints

\begin{tabular}{|c|c|c|c|c|}
\hline Specimen & 1 & 2 & 3 & 4 \\
\hline $\begin{array}{l}\text { Average tensile } \\
\text { strength (MPa) }\end{array}$ & 354.5 & 370 & 341.5 & 361.5 \\
\hline
\end{tabular}

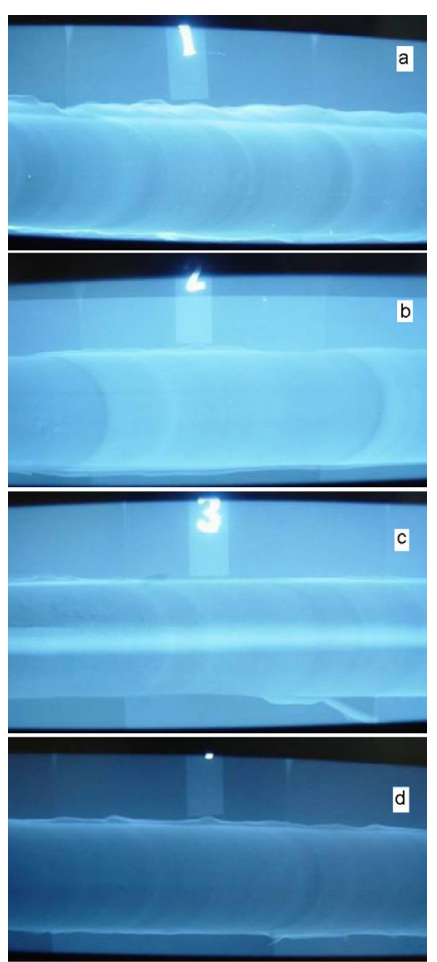

Fig. 2 Radiographic inspection photos of specimens.

dure can ensure the weld bead to be fully penetrated in the range of $0.8 \mathrm{~mm}$ size deviation, and meet the nondestructive testing requirements of the friction stir welds in the annular joint.

Table 2 is the test sheet for tensile properties of the weld joints. Among the tensile properties of the four types of welds, the tensile strength of №2 specimen is the highest, $370 \mathrm{MPa}$; and the tensile strength of the №3 specimen is the lowest, which is 341.5MPa.

Fig. 4 shows the fracture position of the tensile test of four specimens, of which the fracture position of the №1, №2 and №4 specimens are the position of the back side of the weld bead, the shear angle is $45 \mathrm{de}-$ grees, and the fracture position of the №3 specimen is the fracture at the bead of the original root. The black line in the picture is the original weld position [9].

Bending test experiment only carries out the root bend test. The purpose is to check whether the root of the weld bead is weakly

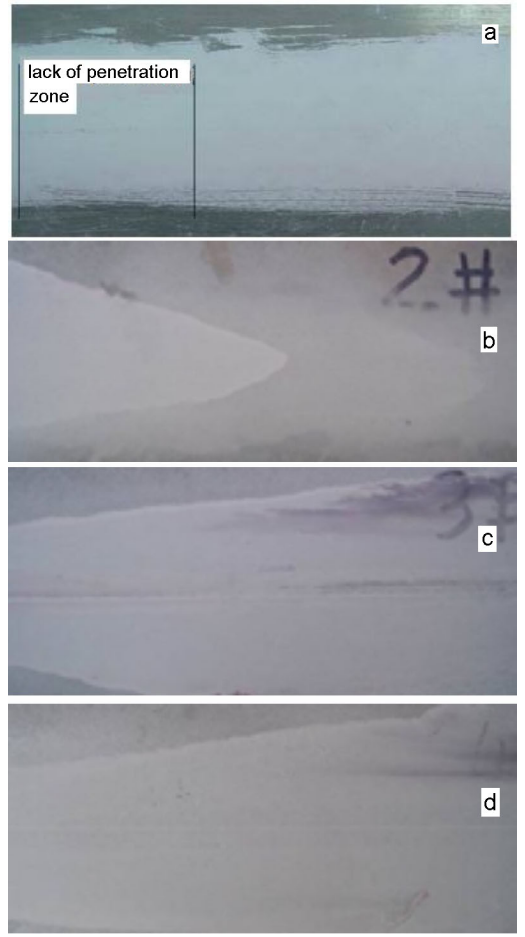

Fig. 3. Root coloring test results.

connected or loose. Table 3 is the bending angle for the root of weld joint of the samples. It can be seen that the bending angle of №3 specimen is the smallest, 17 degrees, the maximum angle of №4 specimen is 97 degrees, №1 and №2 specimens are around 55 degrees. Fig. 5 is a material object photograph of four bending specimens. Among them, the crack initiation position of №3 is the original root weld, and it is straight crack along the position of the original weld. The №1, №2 and №4 cracks are not at the original weld position.

The results of the two mechanical tests show that: (1) the tensile properties of the weld beads formed by the back plate type friction stir welding are the highest, and the bending properties are in accordance with the common friction stir welds [10]; (2) the root slotted friction stir welding has better bending performance; (3) there is a linear defect in the weld root of support plate slotted friction stir welding, and the radiographic flaw detection and root coloring are difficult to identify.

Table 3. Test sheet for bending angle of the weld root

\begin{tabular}{||c|c|c|c|c||}
\hline Specimen & 1 & 2 & 3 & 4 \\
\hline Bending angle ( $\left.{ }^{\circ}\right)$ & 57 & 55 & 17 & 97 \\
\hline
\end{tabular}




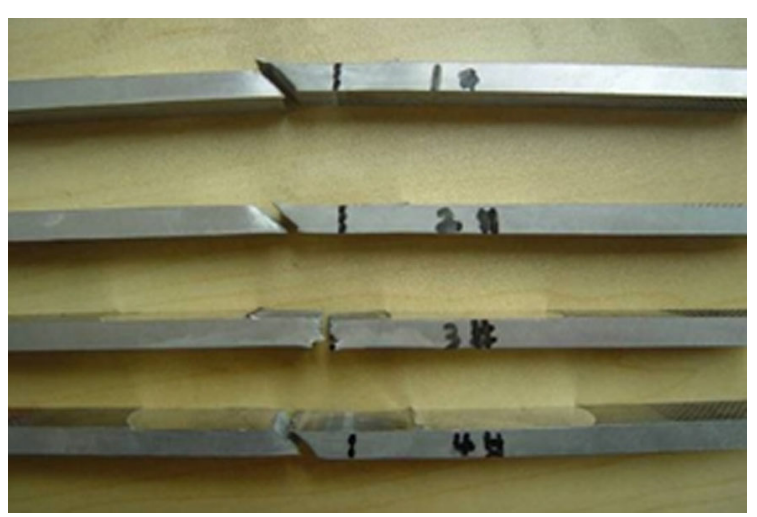

Fig. 4. Fracture position of the specimens.

The forming mechanism of friction stir welds has been studied by many scholars, mainly from the plastic flow of the weld material and the formation procedure of the weld zone [11]. This paper focuses on the study of the microstructure properties of the weld root under different full penetration. Because of the constant welding parameters, the cause of change of the weld performance is the change of the weld root procedure. The reasons for the change of microstructure properties of the weld are analyzed by the formation of the microstructure of the weld root.

For the selection of weld metallographic section position, №1, №3 and №4 specimens are selected the most thick and there is no position of lack of penetration defect in the back coloring experiment, and the №2 sample selects the thinnest area in the weld position. The above conditions are the most harsh conditions for weld formation under various welding procedures. As long as the weld properties in this state are good enough, the microstructure properties of the welds in other positions can be guaranteed.

The shape of the onion ring is a typical structure in the welding zone of the friction stir weld. The circular ring outlines the path of the material moving above the lower direction, while the center of the circle is the position of zero horizontal moving velocity of the material. The material below the center moves along the circular contour away from the center of the weld. For №1, №3 and №4 specimens, the same stirring tool is used in the procedure test. Under the unified welding parameters, the position of the center of the circular ring can be used to characterize the flow change of the weld material. This can be used to analyze the forming characteristics of the weld in the root slotting and the supporting plate slotting procedure.

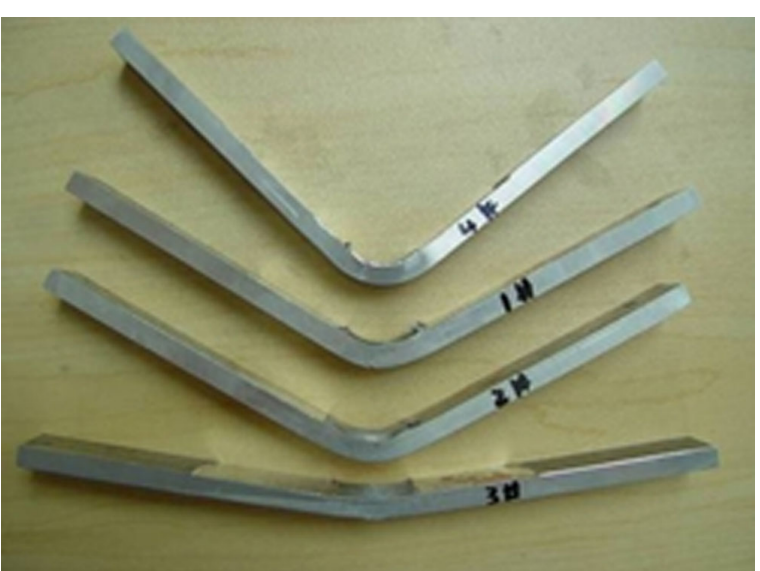

Fig. 5. Root bending test result of specimens.

Fig. 6 is a metallographic photograph of the root of weld for specimen №1. The microstructure of weld root belongs to the nugget area [12]. From Fig. 6 (a), it can be seen that there is no contour line in a region near the bottom of the weld, that is, there is no large-scale upward migration of the material in this area. The height of this area is $0.6 \mathrm{~mm}$. Figs. $6 \mathrm{~b}-\mathrm{d}$ are magnified photos of this area, in which (b) is the root photo, (c) as the advancing side photo, (d) for the retreating side photo. The advancing side is the equiaxed zone, the back side is the heat affected zone, and the root is a hybrid zone between the equiaxed and the heat affected areas, and there is a "S" weakness connection defect. These results indicate that the material near the root of the weld is not stirred by a probe, and the end of probe presses the material downward. Most of the materials migrate in the direction of the advancing side and lead to the equiaxed crystal near the advancing side. Although the gap of the root weld is affected by thermal effect, it has disappeared, but no metallurgical connection has been formed, resulting in weak connection defects. This defect can slightly reduce the tensile strength of the weld, but the most serious is to reduce the back bending property of the weld. The existing research results show that the weak connection has a great influence on the fatigue performance of the joint, which greatly reduces the fatigue strength of the joint, and often becomes the starting point of the fatigue crack.

Fig. 7. is the microstructure pattern of the weld root of №3 specimen.

From the root image of Fig. 7 a, it can be seen that a large number of heat affected zone tissues appear at the weld root, and among which weak connections also found. 

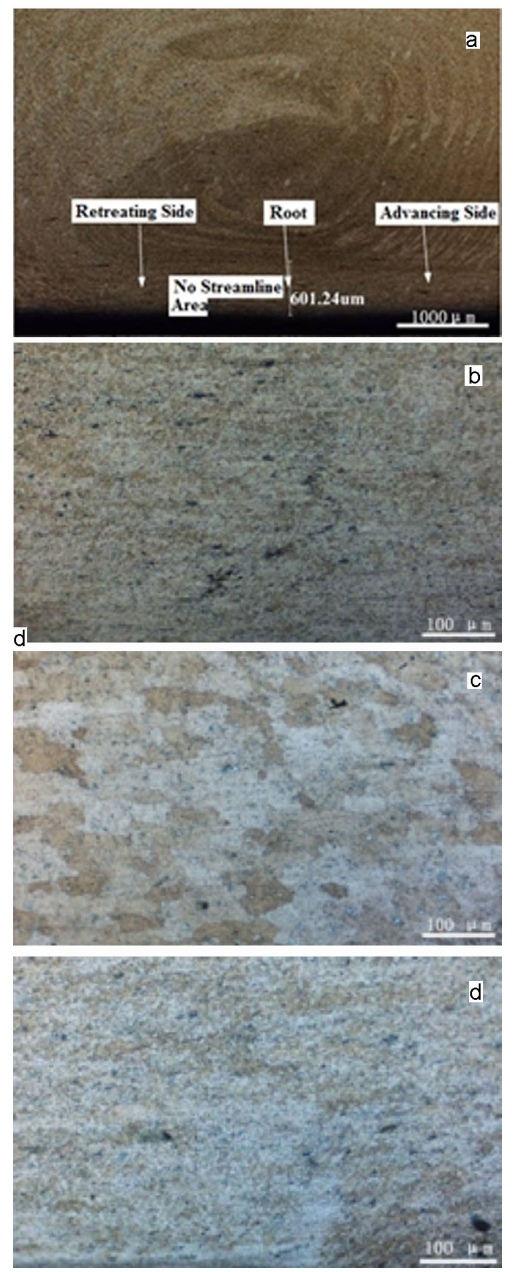

Fig. 6. Metallographic photo of the weld root of №1 specimen. a) full weld appearance; b) root part magnification; c) retreating side magnification; d) advancing side magnification.

Amplification near the end of weak connection is shown in Fig. 7 b. It can be seen that the weld root is distributed up by the HAZ (heat affected zone), the TMAZ (thermo-mechanically affected zone) and the nugget zone (weld nugget), and the micro cracks are terminated in the TMAZ. From the above mechanical performance test, it can be concluded that the performance of №3 welded joint is the worst, and this micro cracks should be an important reason for its sharp decline in performance. This sample is used in shoe plate slotting welding procedure, the slot depth of $0.6 \mathrm{~mm}$, by ball cutter. It is shown from Fig. $7 \mathrm{c}$ that the microstructure of the root material of the weld appears to show the weld heat affected zone morphology, and the weak connection is offset to the advancing side by the vertical upward direction, which indicates that

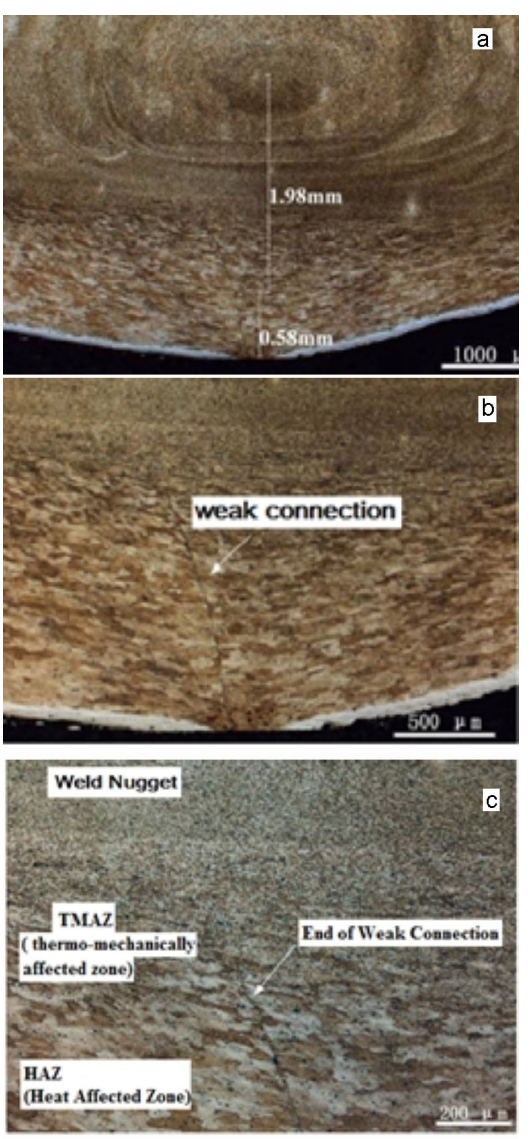

Fig. 7. Microstructure photo of the weld root of 3 \# specimen. a) root image, b) amplification near the end of weak connection, c) microstructure amplification of the weld root.

the back material of the weld is moved down to the empty slot position of the supporting plate rapidly under the action of the forging force of the probe. With the mechanical agitation of the probe, the mass transfer of the material does not occurred, the position of lack of penetration is the position of the original weld, the transfer of the material can be reacted with left offset of lack of penetration. When the weak connection defect to the heat affected zone showed that the material have been migrated on a large scale, the weak connection completely disappeared. It is measured that the weak connection length is $1.2 \mathrm{~mm}$, the $0.6 \mathrm{~mm}$ of the slot depth is removed, the weak connection still has $0.6 \mathrm{~mm}$, and the common friction welding weld seam with the same welding condition has no weak connection defect, which shows that the shoe plate slotting friction stir welding procedure has the disadvantage in increasing the penetration and eliminating the weak connection defects. 


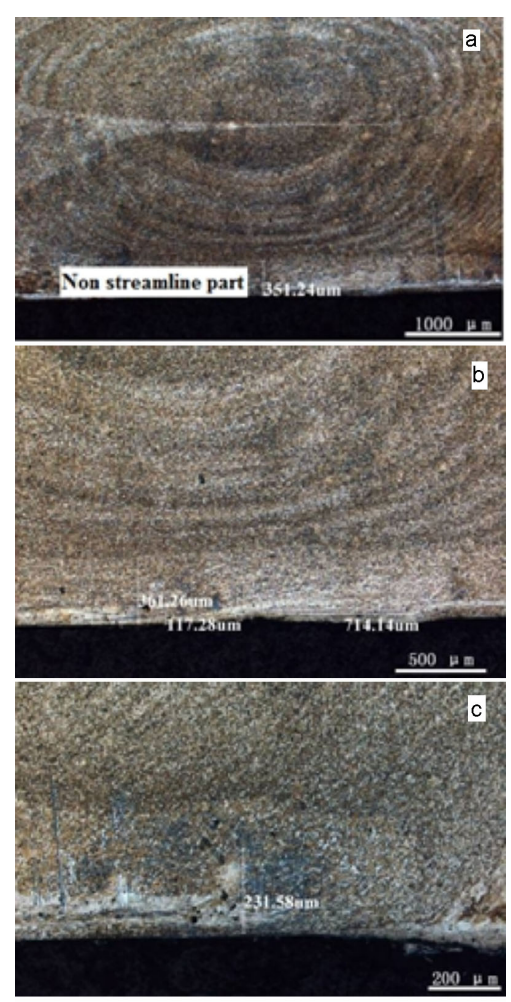

Fig. 8. Metallographic photo of the weld root of №4 specimen; a) macroscopic appearance of weld nugget; b) root of the weld; (c) magnifying photo of long strip solid solution.

Fig. 8 is the metallographic photograph of the weld root of 4 \# specimen, in which (a) is the macroscopic appearance of the whole weld nugget, showing the "onion" shape. There is still a zone without "onion" pattern at the root of the weld as 1 \# sample. Its thickness is $0.36 \mathrm{~mm}$ and the thickness of $1 \#$ is smaller than $0.24 \mathrm{~mm}$, which illustrates the material under this kind of procedure. The migration range is extended to the depth direction. (b) for the root region, its tissue is more homogeneous than that of $1 \#$. There is no structure of the heat affected zone in the advancing side and the retreating side, but there is a long strip of white phase at the bottom of the plate. The white phase spectrum analysis data shows that the solid solution organization with high $\mathrm{Al}$ content.

Fig. $8 \mathrm{c}$ is magnified photographs of the solid solution of the bottom strip. It is found that the thickness of the solid solution is about $0.12 \mathrm{~mm}$, the maximum edge reaches $0.23 \mathrm{~mm}$, and the upper layer of the solid solution is a fine equiaxed structure. Scanning near the root of the white solid solution revealed that there existed horizontal weak connection defects near the phase.
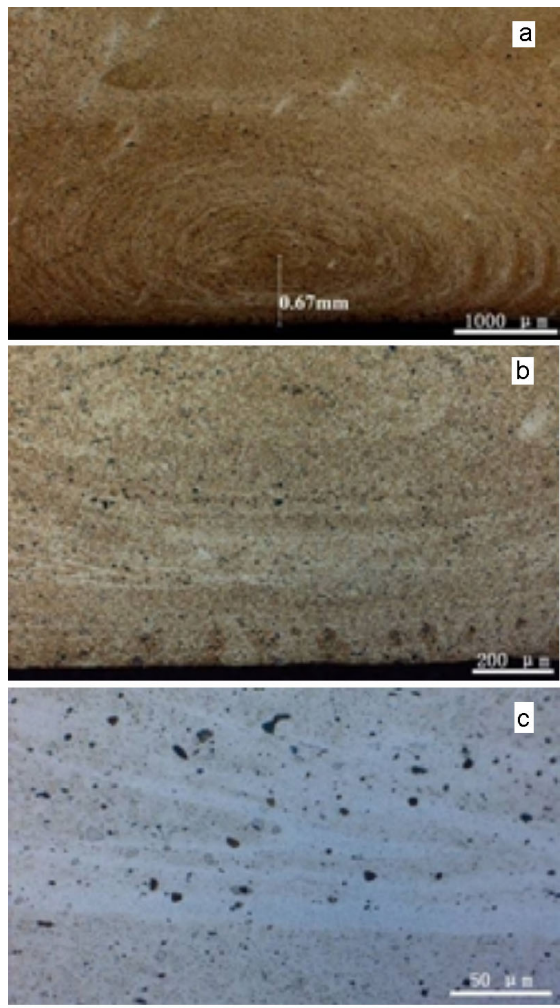

Fig. 9. Metallographic photo of the weld root of №2 specimen.

The №4 sample is used in the form of root slotting, because there is space on the back and the straight line disappears. In the process of friction stir welding, the material from the solid circle extrusion zone at the end of the probe can fill here quickly. This is the reason why there is no " $\mathrm{S}$ " weak connection and no heat affected structure in the retreat side of the specimen. However, because of the direct contact with the shoe plate, the heat dissipation is fast, the temperature of the extruded material in this area is rapidly reduced, and the solid solution structure is formed in a strip shape, and the weak connection defect is easily formed because of the lack of heat. It is shown from the previous performance test that because the weld root has a wide equiaxed grain region, the plasticity is better and the back bending performance is better, but the tensile property is $2.3 \%$ lower than that of the back plate type weld, because of the long strip solid solution with the thickness of $0.12 \mathrm{~mm}$ and the existence of horizontal weak connections.

The №2 specimen is the procedure of back plate, and the material of the back plate is $0.5 \mathrm{~mm} 2 \mathrm{~A} 12$ plate. The advantage of this procedure is that the pad material can provide material for the original weld 


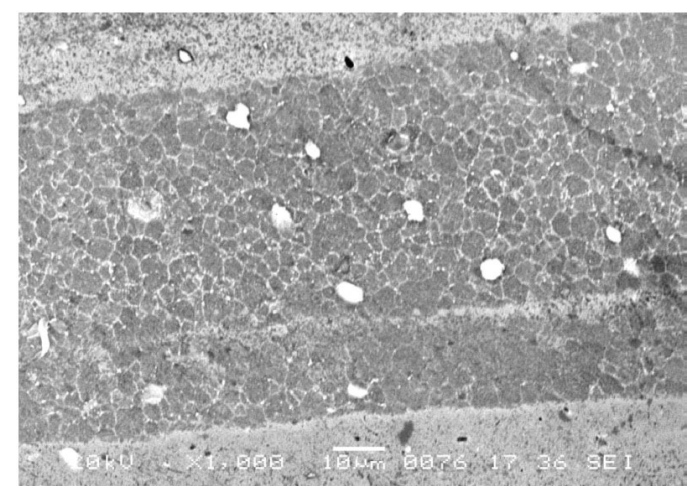

Fig. 10. Scanning photo near the streamline stripe of №2 specimen.

material, and by observing whether the backside pad is connected with the original weld material, it can feed back the full penetration of the weld, and can completely avoid the defects of the lack of penetration and weak connection.

Fig. 9 is the metallographic photo of the weld root of the №2 specimen. Compared with the other welding procedures, the ring of the №2 weld is the most flat and the center distance of the ring is the smallest distance, $0.67 \mathrm{~mm}$. This is the result of a long mixing probe, that is, the whole weld is in the weld nugget area and the weld nugget area is still a typical "onion" like structure and made up of black and white rings. Through the energy spectrum analysis, the white ring is an aluminum based solid solution with low $\mathrm{Cu}$ content (1.23\%), while the black ring is an aluminum based solid solution containing a large amount of $\mathrm{Cu}(3.46 \%)$.

Fig. 10 is scanned photographs of the vicinity of streamline stripes. It can be seen that there are precipitates in the grain boundaries of equiaxed grains, and there are blocky precipitates. The black granular dispersed phase is distributed throughout the weld area and it is ellipsoidal $\left(\mathrm{CuAl}_{2}\right)$ phase by energy spectrum analysis. Compared with the above three kinds of weld beads, the precipitated phase in the weld $\theta$ $\left.(\mathrm{CuAl})_{2}\right)$ is obviously larger. This is a probe with a long mixing needle, and the heat transfer effect between the weld plate and the supporting plate is weakened because of the back plate. The increase of heat in the weld leads to the increase of the precipitate phase in the weld nugget and the plastic deterioration of the material in the weld nugget area. It is also the reason for the decline of the back bending properties of №2 specimen.
The back plate procedure adds a contact interface because of the back plate, and the interface material will have some part into the weld bead. Therefore, it is necessary to clean the surface of the pad material to eliminate the oil pollution and the oxide film. The feasibility of such technological measures has been proved. To sum up, the weld structure under this procedure has excellent tensile properties, and it can ensure that there will be no defect of incomplete penetration and weak connection.

\section{Conclusions}

In this paper, the validity of the three kinds of fully penetrated friction stir welding procedure is verified. Through the mechanical properties test and metallographic test of the weld, the forming and the microstructure of the weld are analyzed. The following conclusions can be drawn.

When the material size deviation is $0.5 \mathrm{~mm}$, the common friction stir welding (FSW) does not meet the manufactural requirements of special friction stir welding.

For shoe plate welding procedure, the weld quality is the worst, and there are a large number of heat affected zones in the root of the weld. There are obvious weak connection defects in this structure, which leads to the drastic decline in tensile properties and back bending properties. Such welding procedures with poor weld performance and weak connection defects are difficult to identify by conventional backside coloring test and are not suitable for practical production.

The weld bead of the back plate type friction stir welding presents the macroscopic appearance of "onion", and the microstructure is the typical equiaxed grain structure of the weld nugget. The weld has the most excellent tensile properties and the weld backbending performance is not the best. This is the high heat transfer of the weld in the procedure test, which leads to the $\mathrm{CuAl}_{2}$ precipitation of the weld nugget, lower the plasticity of the joint. This procedure can ensure that the weld root will not have the defects of lack of penetration and weak connection. The testing method is simple and convenient, and it is the best choice for the full penetration procedure of the special friction stir welding.

The weld structure of the slotted weld on the back of the weld plate shows obvious equiaxed grain structure, and no "onion" appearance occurs, but there are some lumpy aluminum base solid solution struc- 
tures at the bottom of the weld, and the weak connection defects are scattered. This weld structure has the best back bending performance, but the tensile strength of the weld bead is decreased by $2.3 \%$ relative to the back plate type, and the existence of the horizontal weak connection could lead to deterioration of the fatigue and corrosion performance of the weld. The weak connection defect of the welding seam for this procedure can only be identified by the metallographic analysis and the conventional back coloring experiment can not be identified, which is not conducive to the production application. In addition, due to the shoe plate slotting, the material loss of welded joint is large, which leads to further reduction of weld performance.

\section{Acknowledgements}

This work was financially supported by the Fujian Natural Science Foundation (2018J01493).

\section{References}

1. Q.Y. Zhao, Z.S. Wu, C.R. Liu et al., Welding Techn., 45, 1 (2016).

2. G.Q. Wang, Y.H Zhao, Y.F. Hao, J.Mater. Scien.Techn., 34, 73 (2018).

3. M. Prapas, N. Jennarong, P. Woraphot, J. Wuhan Univ. Techn. (Mater. Sci.), 32, 1420 (2017).

4. L. Wang, H. Li, S. Zhou et al., Trans. Nonferrous Metals Soc.China, 26, 2830, (2016).

5. J. Kang, S.Y. Liang, A.P. Wu et al., Acta Metallurg. Sinica, 53, 358 (2017).

6. G.K. Padhy, C.S. Wu, S. Gao, J.Mater. Sci.Techn., 34, 1 (2017).

7. P. Zeng, Ship \& Ocean Engin., 39, 55 (2010).

8. M. Tabatabaeipour, J. Hettler, S. Delrue et al., NDT \& E Intern., 80, 23 (2016).

9. Y.H. He, L.W. Zhang, C.W. Hu, Mater. Mech. Engin., 32, 37 (2008).

10. L.M. Ke, J.L. Pan, L. Xing et al., Mater. Mech. Engin., 16, 33 (2008).

11. H. Su, C.S. Wu, A. Pittner et al., Energy, 19, 720 (2014).

12. C.H. Luo, L.J. Guo, F.B. Dong et al., Trans. Chin. Weld. Indust. Instit., 37, 90 (2016). 